Abstracta Iranica Iranica

Revue bibliographique pour le domaine irano-aryen

Volume 28 | 2007

Comptes rendus des publications de 2005

\title{
Romān-hā-ye mo'āṣer-e fārsī. Ketāb-e sevvom. Tehrān, Nīlūfar, 1383/2005, 350 p.
}

Julie Duvigneau

\section{OpenEdition}

1 Journals

Édition électronique

URL : http://journals.openedition.org/abstractairanica/21631

DOI : 10.4000/abstractairanica.21631

ISSN : 1961-960X

\section{Éditeur :}

CNRS (UMR 7528 Mondes iraniens et indiens), Éditions de l'IFRI

\section{Édition imprimée}

Date de publication : 15 mai 2007

ISSN : 0240-8910

\section{Référence électronique}

Julie Duvigneau, «Romān-hā-ye mo'āșer-e fārsī. Ketāb-e sevvom. Tehrān, Nīlūfar, 1383/2005, 350 p. », Abstracta Iranica [En ligne], Volume 28 | 2007, document 372, mis en ligne le 18 septembre 2007, consulté le 25 septembre 2020. URL : http://journals.openedition.org/abstractairanica/21631 ; DOI : https://doi.org/10.4000/abstractairanica.21631

Ce document a été généré automatiquement le 25 septembre 2020.

Tous droits réservés 


\title{
Romān-hā-ye mo'āṣer-e fārsī. Ketāb-e sevvom. Tehrān, Nīlūfar, 1383/2005, $350 \mathrm{p}$.
}

\author{
Julie Duvigneau
}

1 Troisième tome de la série de Mīr Șādeqī, le présent volume présente dix-huit romans, parus entre 1969 et 2004, d'écrivains de la seconde génération, qui ont commencé leur activité littéraire dans les années cinquante : Sā‘edī, Mīr Șādeqī, Dowlatābādī, Aḥmad Maḥmūd, Barāhenī, Taqī Modaressī et Maḥmūd Kīānūš. L'étude de chaque texte suit la méthode inaugurée dans les deux premiers volumes: une fiche technique (contenu, structure, situation spatio-temporelle, noms des personnages, genre littéraire et point de vue), un résumé critique (succinct étant donné le volume de l'ouvrage), le synopsis de l'intrigue et enfin, des morceaux choisis. Le présent volume s'enrichit d'un glossaire de termes de critique littéraire, ainsi que d'un index des écrivains et des romans présentés dans les trois premiers volumes.

2 L'A. envisage de continuer cette série qui prévoyait initialement trois volumes en s'occupant des auteurs de la troisième génération, qui ont commencé à publier après 1979.

3 Le lecteur ne peut que se réjouir de l'ampleur prise par le projet, qui se révèle non seulement un ouvrage destiné aux chercheurs en littérature, mais également une introduction à tous les lecteurs potentiels de littérature iranienne, qui peuvent trouver ici des repères pour l'exploration d'une production gigantesque. 
INDEX

Thèmes : 11.1.2. Littérature persane moderne

\section{AUTEURS}

JULIE DUVIGNEAU

Paris 